Research Paper

\title{
Tree survival and growth are impacted by increased surface temperature on paved land
}

\author{
Yuanyuan Chen ${ }^{\mathrm{a}}$, Xiaoke Wang ${ }^{\mathrm{a}, *}$, Bo Jiang ${ }^{\mathrm{b}}$, Zhi Wen $^{\mathrm{a}}$, Ning Yang ${ }^{\mathrm{a}}, \mathrm{Li} \mathrm{Li}^{\mathrm{a}}$ \\ a State Key Laboratory of Urban and Regional Ecology, Research Center for Eco-Environmental Sciences, Chinese Academy of Sciences, Beijing 100085, China \\ b Chang Jiang Water Resources Protection Institute, Wuhan 430051, Hubei, China
}

\section{H I G H L I G H T S}

- Pavements could significantly increase surface temperature.

- Soil moisture responses to pavement varied with tree species and spacing.

- Surface temperature and soil moisture both decreased with decreasing tree spacing.

- The presence of pavements reduced tree growth including height and basal diameter.

- Pervious pavement may not alleviate the reduction in tree growth due to heat stress.

\section{A R T I C L E I N F O}

\section{Article history:}

Received 3 December 2015

Received in revised form 11 January 2017

Accepted 3 February 2017

Available online 23 February 2017

\section{Keywords:}

Tree growth

Pervious pavement

Surface temperature

Soil moisture

Survival rate

Tree spacing

\begin{abstract}
A B S T R A C T
Trees are increasingly planted within paved environments in cities. However, little is known regarding growth responses of trees to different pavements. In this study, three popular urban forest tree species, pine (Pinus tabuliformis Carr.), ash (Fraxinus chinensis), and maple (Acer truncatum Bunge), were planted on different paved and unpaved plots (pervious brick pavement, impervious brick pavement, and no pavement as the control) at three different spacing $(0.5 \mathrm{~m} \times 0.5 \mathrm{~m}, 1.0 \mathrm{~m} \times 1.0 \mathrm{~m}$, and $2.0 \mathrm{~m} \times 2.0 \mathrm{~m}$ apart $)$. Results showed that pavement significantly increased surface temperature, changed soil moisture, and decreased survival rate of maple, and height and basal diameter increments of all three species, except for ash at the $0.5 \mathrm{~m} \times 0.5 \mathrm{~m}$ spacing. There were significant interactions between pavement and spacing on tree height and basal diameter increments. Linear regression analysis showed that increased surface temperature was the primary contributor to decreased tree survival and growth. Therefore, alleviating the increased surface temperature induced by the pavement is important for guaranteeing tree survival and growth.
\end{abstract}

(c) 2017 Elsevier B.V. All rights reserved.

\section{Introduction}

Urban trees can provide a wide range of ecosystem services to enhance the quality of life for residents (Ridder et al., 2004). They can reduce storm water flow by increasing rainfall interception (Xiao \& McPherson, 2002), alleviate urban heat island effects by increasing evaporative cooling and providing shade (Mullaney, Lucke, \& Trueman, 2015; Shashua-Bar, Potchter, Bitan, Boltansky, \& Yaakov, 2010), improve air quality by absorbing gas and par-

\footnotetext{
* Corresponding author.

E-mail addresses: chenyuanyuan0822@163.com (Y. Chen), wangxk@rcees.ac.cn (X. Wang), jbshuibao415@126.com (B. Jiang),wz166@126.com (Z.Wen), xiaozhi_1986@163.com (N. Yang), lili7381741@yeah.net (L. Li).
}

ticulate pollutants (Beckett, Freer-Smith, \& Taylor, 1998), and reduce noise by absorbing sound and providing quiet environments (Lohr, Pearson-Mims, Tarnai, \& Dillman, 2004). However, trees are typically surrounded by impervious pavements such as parking lots, roads, and driveways, which can alter soil microenvironments through increased soil surface and rhizospheric temperature (Arnfield, 2003; Tang et al., 2011), decreased rainwater infiltration (Lee \& Heaney, 2003), blockage of soil-air gas exchange (Balakina et al., 2005; Feng, Wu, \& Letey, 2002), reduced nutrient availability (Zhao, Li, Wang, Yang, \& Ni, 2012), and altered energy and water balances (Morgenroth \& Buchan, 2009). Trees planted in and around areas of impervious pavement often have poor growth and shorter life spans than trees growing in natural environments and thus generally require more protection (Bühler, Kristoffersen, \& Larsen, 2007; Volder, Viswanathan, \& Watson, 2014). Researchers 

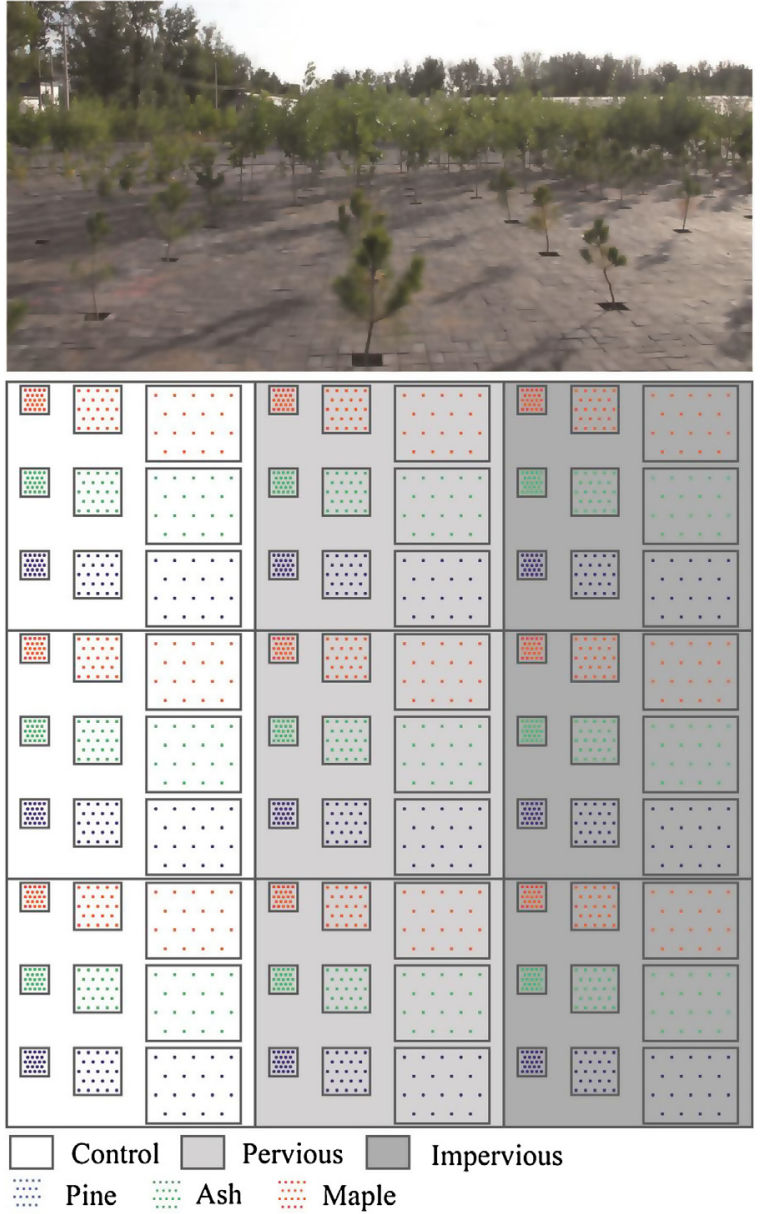

Fig. 1. A photograph of a sample plot (upper) and a diagram of the experimental design (lower).

have found that the survival, health, and growth rates of urban trees are influenced by both site characteristics and human activity (Lawrence, Escobedo, Staudhammer, \& Zipperer, 2012; Lu et al., 2010). Berrang, Karnosky, and Stanton (1985) found that poor tree growth was often associated with insufficient water availability, and that impervious surfaces could affect tree growth by restricting water from infiltrating into the soil, thereby decreasing water availability for tree uptake (Balakina et al., 2005; Kozlowski, 1999; Mueller \& Day, 2005). Impervious pavements can also store more heat and cause higher temperatures in the upper soil layers (Tang et al., 2011), which may weaken root growth and even kill tree roots when temperatures are too high (above $40^{\circ} \mathrm{C}$ ) (Celestian \& Martin, 2004; Martin \& Ingram, 1991).

Tree growth rate and health growing under impervious pavements are generally threatened (Grabosky, Bassuk, Irwin, \& Van Es, 2001). Mueller and Day (2005) showed that trees planted in open lawn sites have better growth than those in sites surrounded by impervious pavements. In addition, the height and diameter at breast height of trees in nonpaved surfaces are often higher in the comparison to areas of impervious pavement (Grabosky \& Gilman, 2004; Mullaney et al., 2015; Rahman, Stringer, \& Ennos, 2013). Furthermore, trees grown on pavements in urban environments face compounding stresses, such as restricted soil moisture extremes (Berrang et al., 1985), soil temperature (Graves, 1994), soil compaction (Philip \& Azlin, 2005), soil chemicals pollution (Marosz \& Nowak, 2008), air pollution (Su \& Sun, 2006), species tolerance (Lu et al., 2010), and physical injuries to stems and branches of plants (Lakovoglou, Thompson, Burras, \& Kipper, 2001).
Higher water availability, lower temperatures, and higher root zone oxygen typically improve the health and growth of trees (Balakina et al., 2005; D'Amato, Sydnor, Knee, Hunt, \& Bishop, 2002; Kozlowski, 1999). Therefore, researchers have proposed using pervious pavement (pervious materials including gravel, crushed stone, open paving blocks, and porous bricks) instead of impervious pavement to support soil conditions beneath pavements that are more conducive to tree growth (Morgenroth \& Visser, 2011; Mullaney \& Lucke, 2014; Mullaney et al., 2015; Volder, Watson, \& Viswanathan, 2009). Compared to impervious pavements, pervious pavements have high infiltration rates of water and oxygen, which help reduce the stress experienced by urban trees (Bean, Hunt, \& Bidelspach, 2007; Dietz, 2007). This could potentially improve productive conditions for tree root growth and activity (Morgenroth, 2011; Viswanathan, Volder, Watson, \& AitkenheadPeterson, 2011). Morgenroth and Visser (2011) also showed that pervious pavements could increase tree stem height, diameter, and biomass of oriental plane tree seedlings. However, results were not always consistent for all studies. Volder et al. (2009) found that the relative growth rates of tree trunk diameters were similar across three different pavement types (no pavement, pervious, and impervious pavements).

Although several studies have focused on identifying the influence of different pavement types on tree performance (Morgenroth \& Visser, 2011; Viswanathan et al., 2011; Volder et al., 2009), these have mostly been studies of single tree species without consideration of spacing influences. Most of the previous studies also have used in-situ measurements, which have specific limitations due to uncontrolled interference from the surrounding environment and human activity.

The objective of this study was to investigate how pavements with varying spacing would affect the growth of urban seedling trees. The field study was established to test the following hypotheses: (1) soil moisture under pervious pavement is greater than under impervious pavement and non-pavement, (2) the survival rates of trees in plots with pervious pavement are higher than impervious pavement, and (3) trees growing in pervious pavement will exhibit greater height and diameter growth than those growing in impervious pavement. The results of this study have the potential to assist urban landscape designers and urban foresters in designing and managing pavement systems that improve the growth of trees planted in urban environments.

\section{Methods}

\subsection{Site description}

The field experiment was conducted at Zhangtou village, Changping District, Beijing, China $\left(40^{\circ} 12^{\prime} \mathrm{N}, 116^{\circ} 08^{\prime} \mathrm{E}\right)$. The area has a temperate continental monsoon climate with four distinct seasons. The mean annual rainfall is $542 \mathrm{~mm}$ with the majority of rainfall occurring from June to September. The mean annual temperature is $12.1^{\circ} \mathrm{C}$ and the maximum and minimum air temperatures are $41.4^{\circ} \mathrm{C}$ and $-19.6^{\circ} \mathrm{C}$ respectively (Local Chronicles Office of Changping District of Beijing, 2012). The soil texture at the test site is defined as sandy loam, and the bulk density is $1.5 \mathrm{~g} / \mathrm{cm}^{3}$, mean soil organic matter content $16.4 \mathrm{~g} / \mathrm{kg}$, total nitrogen $0.9 \mathrm{~g} / \mathrm{kg}$, available phosphorus $38.1 \mathrm{mg} / \mathrm{kg}$, available potassium $102.1 \mathrm{mg} / \mathrm{kg}$, and soil pH value 8.3 (Tong et al., 2011).

\subsection{Experimental design}

A factorial split-plot experimental design was used to divide the study area (previous cropland) into three equal zones for three pavement types: (1) pervious bricks pavement, (2) impervious 
Table 1

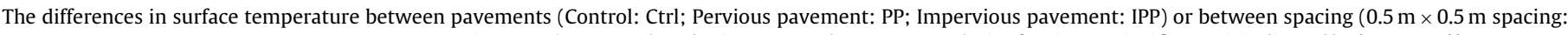

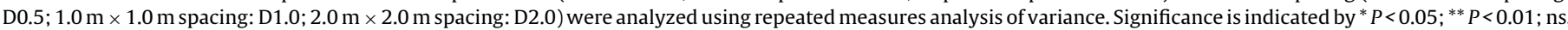
not significant.

\begin{tabular}{|c|c|c|c|c|c|c|c|}
\hline \multirow[t]{2}{*}{ Spacing } & \multicolumn{3}{|c|}{ Mean difference $\left({ }^{\circ} \mathrm{C}\right)$} & \multirow[t]{2}{*}{ Pavement } & \multicolumn{3}{|c|}{ Mean difference $\left({ }^{\circ} \mathrm{C}\right)$} \\
\hline & PP-Ctrl & IPP-Ctrl & IPP-PP & & D1.0-D0.5 & D2.0-D0.5 & D2.0-D1.0 \\
\hline \multicolumn{8}{|l|}{ Pine } \\
\hline D0.5 & $1.50 \pm 0.56^{*}$ & $0.80 \pm 0.56 \mathrm{~ns}$ & $-0.70 \pm 0.56 \mathrm{~ns}$ & Ctrl & $0.75 \pm 0.43 \mathrm{~ns}$ & $1.08 \pm 0.43^{*}$ & $0.33 \pm 0.43 \mathrm{~ns}$ \\
\hline D1.0 & $6.06 \pm 0.47^{* *}$ & $3.92 \pm 0.47^{* *}$ & $-2.14 \pm 0.47^{* *}$ & $\mathrm{PP}$ & $5.31 \pm 0.52^{* *}$ & $8.19 \pm 0.52^{* *}$ & $2.87 \pm 0.52^{* *}$ \\
\hline D2.0 & $8.60 \pm 0.49^{* *}$ & $5.05 \pm 0.49^{* *}$ & $-3.55 \pm 0.49^{* *}$ & IPP & $3.87 \pm 0.58^{* *}$ & $5.34 \pm 0.58^{* *}$ & $1.46 \pm 0.58^{*}$ \\
\hline \multicolumn{8}{|l|}{ Ash } \\
\hline D0.5 & $0.89 \pm 0.49 \mathrm{~ns}$ & $0.39 \pm 0.49 \mathrm{~ns}$ & $-0.50 \pm 0.49 \mathrm{~ns}$ & Ctrl & $-1.05 \pm 0.46 \mathrm{~ns}$ & $-0.55 \pm 0.46 \mathrm{~ns}$ & $0.50 \pm 0.46 \mathrm{~ns}$ \\
\hline D1.0 & $5.10 \pm 0.43^{* *}$ & $2.38 \pm 0.43^{* *}$ & $-2.72 \pm 0.43^{* *}$ & $\mathrm{PP}$ & $3.17 \pm 0.43^{* *}$ & $5.67 \pm 0.43^{* *}$ & $2.51 \pm 0.43^{* *}$ \\
\hline $\mathrm{D} 2.0$ & $7.11 \pm 0.51^{* *}$ & $5.00 \pm 0.51^{* *}$ & $-2.10 \pm 0.51^{* *}$ & IPP & $0.95 \pm 0.53 \mathrm{~ns}$ & $4.07 \pm 0.53^{* *}$ & $3.12 \pm 0.53^{* *}$ \\
\hline \multicolumn{8}{|l|}{ Maple } \\
\hline D0.5 & $4.48 \pm 0.59^{* *}$ & $3.91 \pm 0.59^{* *}$ & $-0.57 \pm 0.59 \mathrm{~ns}$ & Ctrl & $1.06 \pm 0.42^{*}$ & $1.99 \pm 0.42^{* *}$ & $0.93 \pm 0.42 \mathrm{~ns}$ \\
\hline D1.0 & $8.48 \pm 0.47^{* *}$ & $5.37 \pm 0.47^{* *}$ & $-3.11 \pm 0.47^{* *}$ & PP & $5.06 \pm 0.53^{* *}$ & $6.35 \pm 0.53^{* *}$ & $1.29 \pm 0.53 \mathrm{~ns}$ \\
\hline D2.0 & $8.83 \pm 0.69^{* *}$ & $5.46 \pm 0.69^{* *}$ & $-3.37 \pm 0.69^{* *}$ & IPP & $2.52 \pm 0.76^{*}$ & $3.54 \pm 0.76^{* *}$ & $1.02 \pm 0.76 \mathrm{~ns}$ \\
\hline
\end{tabular}

Table 2

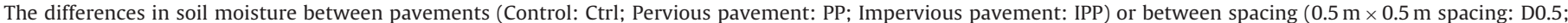

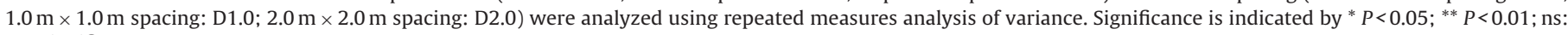
not significant.

\begin{tabular}{|c|c|c|c|c|c|c|c|}
\hline \multirow[t]{2}{*}{ Spacing } & \multicolumn{3}{|c|}{ Mean difference (\%) } & \multirow[t]{2}{*}{ Pavement } & \multicolumn{3}{|c|}{ Mean difference (\%) } \\
\hline & PP-Ctrl & IPP-Ctrl & IPP-PP & & D1.0-D0.5 & D2.0-D0.5 & D2.0-D1.0 \\
\hline \multicolumn{8}{|l|}{ Pine } \\
\hline D0.5 & $4.71 \pm 1.37^{*}$ & $3.19 \pm 1.37 \mathrm{~ns}$ & $-1.52 \pm 1.23 \mathrm{~ns}$ & Ctrl & $2.32 \pm 1.55 \mathrm{~ns}$ & $1.35 \pm 1.55 \mathrm{~ns}$ & $-0.96 \pm 1.38 \mathrm{~ns}$ \\
\hline D1.0 & $8.91 \pm 2.02^{* *}$ & $5.46 \pm 2.02^{*}$ & $-3.46 \pm 2.02 \mathrm{~ns}$ & $\mathrm{PP}$ & $6.51 \pm 0.95^{* *}$ & $6.37 \pm 0.95^{* *}$ & $-0.14 \pm 0.95 \mathrm{~ns}$ \\
\hline D2.0 & $9.73 \pm 1.29^{* *}$ & $9.04 \pm 1.29^{* *}$ & $-0.70 \pm 1.29 \mathrm{~ns}$ & IPP & $4.58 \pm 2.11 \mathrm{~ns}$ & $7.20 \pm 2.11^{*}$ & $2.62 \pm 2.11 \mathrm{~ns}$ \\
\hline \multicolumn{8}{|l|}{ Ash } \\
\hline D0.5 & $-2.51 \pm 1.06 \mathrm{~ns}$ & $-2.94 \pm 1.06^{*}$ & $-0.43 \pm 1.06 \mathrm{~ns}$ & Ctrl & $1.85 \pm 0.77 \mathrm{~ns}$ & $0.25 \pm 0.77 \mathrm{~ns}$ & $-1.60 \pm 0.77 \mathrm{~ns}$ \\
\hline D1.0 & $-3.26 \pm 0.70^{* *}$ & $-3.30 \pm 0.70^{* *}$ & $-0.05 \pm 0.70 \mathrm{~ns}$ & $\mathrm{PP}$ & $1.11 \pm 1.54 \mathrm{~ns}$ & $2.59 \pm 1.54 \mathrm{~ns}$ & $1.49 \pm 1.54 \mathrm{~ns}$ \\
\hline D2.0 & $-0.17 \pm 1.86 \mathrm{~ns}$ & $-1.46 \pm 1.86 \mathrm{~ns}$ & $-1.29 \pm 1.86 \mathrm{~ns}$ & IPP & $1.49 \pm 1.45 \mathrm{~ns}$ & $1.73 \pm 1.45 \mathrm{~ns}$ & $0.24 \pm 1.45 \mathrm{~ns}$ \\
\hline \multicolumn{8}{|l|}{ Maple } \\
\hline D0.5 & $0.52 \pm 1.27 \mathrm{~ns}$ & $-1.86 \pm 1.27 \mathrm{~ns}$ & $-2.38 \pm 1.27 \mathrm{~ns}$ & Ctrl & $0.59 \pm 0.96 \mathrm{~ns}$ & $-0.30 \pm 0.96 \mathrm{~ns}$ & $-0.89 \pm 0.96 \mathrm{~ns}$ \\
\hline D1.0 & $5.06 \pm 1.01^{* *}$ & $-0.76 \pm 1.01 \mathrm{~ns}$ & $-5.81 \pm 1.01^{* *}$ & PP & $5.13 \pm 1.21^{* *}$ & $3.57 \pm 1.21^{*}$ & $-1.56 \pm 1.21 \mathrm{~ns}$ \\
\hline D2.0 & $4.38 \pm 2.50 \mathrm{~ns}$ & $1.34 \pm 2.50 \mathrm{~ns}$ & $-3.05 \pm 2.50 \mathrm{~ns}$ & IPP & $1.70 \pm 2.55 \mathrm{~ns}$ & $2.90 \pm 2.55 \mathrm{~ns}$ & $1.20 \pm 2.55 \mathrm{~ns}$ \\
\hline
\end{tabular}

bricks pavement, and (3) no pavement (i.e., control). In each zone, we used three blocks as replicates, and within each block we had three plots with different spacing: (1) 23 trees with a spacing of $0.5 \mathrm{~m} \times 0.5 \mathrm{~m}$, (2) 23 trees with a spacing of $1.0 \mathrm{~m} \times 1.0 \mathrm{~m}$, and (3) 18 trees with a spacing of $2.0 \mathrm{~m} \times 2.0 \mathrm{~m}$ (Fig. 1 ). Three tree species with the same sequence, pine (Pinus tabuliformis Carr.), ash (Fraxinus chinensis) and maple (Acer truncatum Bunge), were planted in each plot (Fig. 1). In summary, there were nine different treatments (three pavements and three spacing) with three replicates. The plot areas of each tree species were 9,25 , and $80 \mathrm{~m}^{2}$ for $0.5 \mathrm{~m} \times 0.5 \mathrm{~m}, 1.0 \mathrm{~m} \times 1.0 \mathrm{~m}$, and $2.0 \mathrm{~m} \times 2.0 \mathrm{~m}$ of tree spacing, respectively. A shallow ditch was applied to prevent lateral water exchange between the zones with different pavements.

Prior to the experiment, the land was cultivated for wheat and maize production for many years. The area used for treatments of pervious and impervious pavements was compacted and leveled so that the bricks were properly paved. Bricks were paved tightly on the soil surface side by side, and the gaps between impervious bricks were filled with clay soil to prevent water infiltration. Pits of $20 \mathrm{~cm} \times 20 \mathrm{~cm}$ were created after the bricks were paved for tree planting according to the different spacing. All bricks were grey, and the size was $20 \mathrm{~cm} \times 10 \mathrm{~cm} \times 6 \mathrm{~cm}$ (length $\times$ width $\times$ height). The bricks were produced from a mixture of clay, sand, and coal ash. Due to different mixing ratios, the pervious bricks had a coarse surface that was porous (pervious capability of $0.4 \mathrm{~mm} / \mathrm{s}$ ), while the impervious brick surface was smooth and not porous. The albedo of the pervious and impervious bricks measured by radiation meter was $7.13 \%$ and $10.82 \%$, respectively.
Pine, ash and maple were chosen for the study, as they are the most common urban tree species in Beijing (Zhao, 2010). Oneyear-old pine, ash, and maple seedlings were randomly selected to plant on April 16, 2012 after bricks were paved on April 12, 2012. Before the trees were planted the height and basal diameter of all trees were measured. The average heights of pine, ash, and maple seedlings were $77.3 \pm 1.9 \mathrm{~cm}, 118.5 \pm 2.4 \mathrm{~cm}, 44.5 \pm 7.4 \mathrm{~cm}$, respectively, and the average basal diameter was $14.0 \pm 0.5 \mathrm{~mm}$, $14.8 \pm 1.0 \mathrm{~mm}, 6.7 \pm 0.3 \mathrm{~mm}$, respectively.

\subsection{Measurements}

After four months of growth, surface temperature and soil moisture were measured using an infrared thermometer (Optris MS, Optris GmbH, Berlin, Germany) and TDR300 (Spectrum Technologies Inc., Plainfield, IL, USA). From August 2012 to August 2013, one sunny day was selected during each month (except for the four winter months) to measure surface temperature for a total of eight measurements. We measured four times each day at 09:00, 12:00, $15: 00,18: 00$, and each treatment was measured at more than five points. The surface temperature of the day was the average value of the four measurements. We measured soil moisture five times from August 2012 to August 2013. One week after rainfall events, we chose three to five points in each plot to measure soil moisture at a depth of $20 \mathrm{~cm}$. Mean surface temperature and mean soil moisture were the average of measurements over the entire experimental period. 
Survival rates for each plot were recorded as the percentage of trees surviving one year after tree planting in the spring of 2013. Tree height and basal diameter of all trees were monitored monthly over two growing seasons from 2012 to 2013. Tree height was measured as the distance between the soil surface and the tip of the apical bud on the top of each tree, while the diameter was calculated as the average of two measurements taken perpendicular to one another $3 \mathrm{~cm}$ above the soil surface. Tree height and basal diameter increments were calculated as the difference of the measurements in October 2013 and the initial measurement in 2012.

\subsection{Statistical analysis}

Repeated measures of analysis of variance (ANOVA) was used to statistically analyze the differences in surface temperature, soil moisture, tree height and basal diameter among treatments, and two-way ANOVA was used to analyze the difference in survival rates and tree height and basal diameter increments. Post-hoc least significant difference tests were performed only when significant differences were detected by ANOVA. The differences or interactions among treatments were regarded as statistically significant when the $P$ value was less than the significance level of 0.05 . We analyzed the relationship of tree survival rate and growth (height and basal diameter) with mean surface temperature and mean soil moisture using regression analysis and partial correlation analysis. All statistical analyses were carried out using the SPSS 16.0 software (SPSS Inc., Chicago, IL, USA).

\section{Results}

\subsection{Surface temperature}

Surface temperature was elevated on pavements and was higher on pervious pavement than impervious pavement (Fig. 2). The average differences in surface temperature for pine, ash and maple were $5.39 \pm 1.23^{\circ} \mathrm{C}, 4.36 \pm 0.86^{\circ} \mathrm{C}$, and $7.26 \pm 1.04^{\circ} \mathrm{C}$ between pervious pavement and control, respectively; $3.25 \pm 0.85^{\circ} \mathrm{C}, 2.59 \pm 0.68^{\circ} \mathrm{C}$, and $4.91 \pm 0.67{ }^{\circ} \mathrm{C}$ between impervious pavement and control, respectively; and $2.13 \pm 1.47^{\circ} \mathrm{C}, 1.77 \pm 1.05^{\circ} \mathrm{C}$, and $2.35 \pm 1.15^{\circ} \mathrm{C}$ between pervious pavement and impervious pavement, respectively (Table 1). The differences in surface temperature between pavements and control were higher under maple, followed by pine and ash.

It was evident that surface temperature decreased with tree spacing decreased (Fig. 2). The average differences in surface temperature for pine, ash, and maple were $3.31 \pm 0.95^{\circ} \mathrm{C}, 1.02 \pm 0.78^{\circ} \mathrm{C}$ and $2.88 \pm 1.45^{\circ} \mathrm{C}$ between $1.0 \mathrm{~m} \times 1.0 \mathrm{~m}$ and $0.5 \mathrm{~m} \times 0.5 \mathrm{~m}$ spacing, respectively; $4.87 \pm 1.29^{\circ} \mathrm{C}, 3.07 \pm 1.09^{\circ} \mathrm{C}$ and $3.96 \pm 1.50^{\circ} \mathrm{C}$ between $2.0 \mathrm{~m} \times 2.0 \mathrm{~m}$ and $0.5 \mathrm{~m} \times 0.5 \mathrm{~m}$ spacing, respectively; and $1.56 \pm 1.55^{\circ} \mathrm{C}, \quad 2.04 \pm 1.31^{\circ} \mathrm{C}$ and $1.08 \pm 1.81^{\circ} \mathrm{C}$ between $2.0 \mathrm{~m} \times 2.0 \mathrm{~m}$ and $1.0 \mathrm{~m} \times 1.0 \mathrm{~m}$ spacing, respectively (Table 1 ). The differences in surface temperature among different spacing were higher under pine, followed by maple and ash.

\subsection{Soil moisture}

The differences in soil moisture among pavements and control varied with tree species (Fig. 3). For pine and maple, pavements increased soil moisture at the depth of $20 \mathrm{~cm}$, except under maple of $0.5 \mathrm{~m} \times 0.5 \mathrm{~m}$ spacing; while for ash, pavements decreased soil moisture compared with control except with the $2.0 \mathrm{~m} \times 2.0 \mathrm{~m}$ spacing (Fig. 3). Soil moisture in pervious pavement was higher than impervious pavement in most cases, especially for pine and maple trees. Although there were large variations in soil moisture among replicates, the differences were significant between pervious pavement and control for pine at all spacing; for ash at $1.0 \mathrm{~m} \times 1.0 \mathrm{~m}$ spacing; and for maple at $1.0 \mathrm{~m} \times 1.0 \mathrm{~m}$ spacing; between impervious pavement and control for pine at $1.0 \mathrm{~m} \times 1.0 \mathrm{~m}$ and $2.0 \mathrm{~m} \times 2.0 \mathrm{~m}$ spacing; for ash at $0.5 \mathrm{~m} \times 0.5 \mathrm{~m}$ and $1.0 \mathrm{~m} \times 1.0 \mathrm{~m}$ spacing; and between impervious and pervious pavements only for maple at $1.0 \mathrm{~m} \times 1.0 \mathrm{~m}$ spacing (Table 2 ).

The differences in soil moisture between pervious pavement and control increased with increasing tree spacing for pine (Table 2). The results also showed that the differences in soil moisture were significant for pine between $1.0 \mathrm{~m} \times 1.0 \mathrm{~m}$ and $0.5 \mathrm{~m} \times 0.5 \mathrm{~m}$ spacing and $2.0 \mathrm{~m} \times 2.0 \mathrm{~m}$ and $0.5 \mathrm{~m} \times 0.5 \mathrm{~m}$ spacing on pervious pavement, and between $2.0 \mathrm{~m} \times 2.0 \mathrm{~m}$ and $0.5 \mathrm{~m} \times 0.5 \mathrm{~m}$ spacing on impervious pavement; for maple between $1.0 \mathrm{~m} \times 1.0 \mathrm{~m}$ and $0.5 \mathrm{~m} \times 0.5 \mathrm{~m}$ spacing and $2.0 \mathrm{~m} \times 2.0 \mathrm{~m}$ and $0.5 \mathrm{~m} \times 0.5 \mathrm{~m}$ spacing on pervious pavement (Table 2 ).

\subsection{Tree survival rate}

The average survival rates in the next spring after planting were $99.15 \pm 1.83 \%$ for pine, $59.26 \pm 18.12 \%$ for ash, and $67.63 \pm 17.64 \%$ for maple, respectively. The influences of pavements and tree spacing on tree survival rate varied with tree species. No significant differences in survival rates were found between any treatments with different pavements and spacing for pine. Although survival rates on pervious pavements were the highest for ash with $1.0 \mathrm{~m} \times 1.0 \mathrm{~m}$ and $2.0 \mathrm{~m} \times 2.0 \mathrm{~m}$ spacing, followed by survival rates on control and impervious pavement, the differences were not significant (Fig. 4(a)). For maple with $1.0 \mathrm{~m} \times 1.0 \mathrm{~m}$ and $2.0 \mathrm{~m} \times 2.0 \mathrm{~m}$ spacing, survival rates were significantly higher on control than on pavements, and lowest on pervious pavement (Fig. 4(a)).

\subsection{Tree growth}

The height and basal diameter increments of trees grown on control were the highest for pine and maple at all spacing and ash at $1.0 \mathrm{~m} \times 1.0 \mathrm{~m}$ and $2.0 \mathrm{~m} \times 2.0 \mathrm{~m}$ spacing (Fig. 4(b) and (c)). There were significant differences in tree height and basal diameter between control and pavements for pine and maple at all spacing (Table 3). At the end of the second growing period after tree planting on October 11, 2013, the average increments of height and basal diameter were $25.35 \pm 6.14 \mathrm{~cm}$ and $16.11 \pm 2.86 \mathrm{~mm}$ for pine, $183.95 \pm 20.72 \mathrm{~cm}$ and $37.76 \pm 5.62 \mathrm{~mm}$ for ash, and $119.18 \pm 32.31 \mathrm{~cm}$ and $19.46 \pm 5.28 \mathrm{~mm}$ for maple, respectively.

There were also significant differences in height and basal diameter increments among pavement and spacing treatments (Fig. 4(b) and (c)). As compared with control, tree heights averaged for all spacing for pine, ash, and maple were decreased by $28.8 \%,-1.5 \%$, and $43.6 \%$ on pervious pavement, respectively, and by $38.6 \%, 16.3 \%$, and $32.4 \%$ on impervious pavement, respectively. As compared with control, tree basal diameters averaged for all spacing for pine, ash, and maple were decreased by $25.3 \%,-1.9 \%$, and $40.9 \%$ on pervious pavement, respectively, and by $22.8 \%, 6.4 \%$, and $29.9 \%$ on impervious pavement, respectively.

For the lowest spacing of $0.5 \mathrm{~m} \times 0.5 \mathrm{~m}$, pervious pavement increased height and basal diameter of ash by $13.9 \%$ and $12.8 \%$, respectively, relative to the control, and by $9.2 \%$ and $12.4 \%$, respectively, relative to impervious pavement. With increasing spacing, ash height significantly increased for control and pervious pavement, and basal diameter significantly increased for pine and ash on all pavements and for maple on control and impervious pavement (Fig. 4(b) and (c)).

\subsection{The relationship between survival rate and surface temperature and soil moisture}

Survival rates of maple were significantly influenced by pavement, and there were significant relationships between survival 


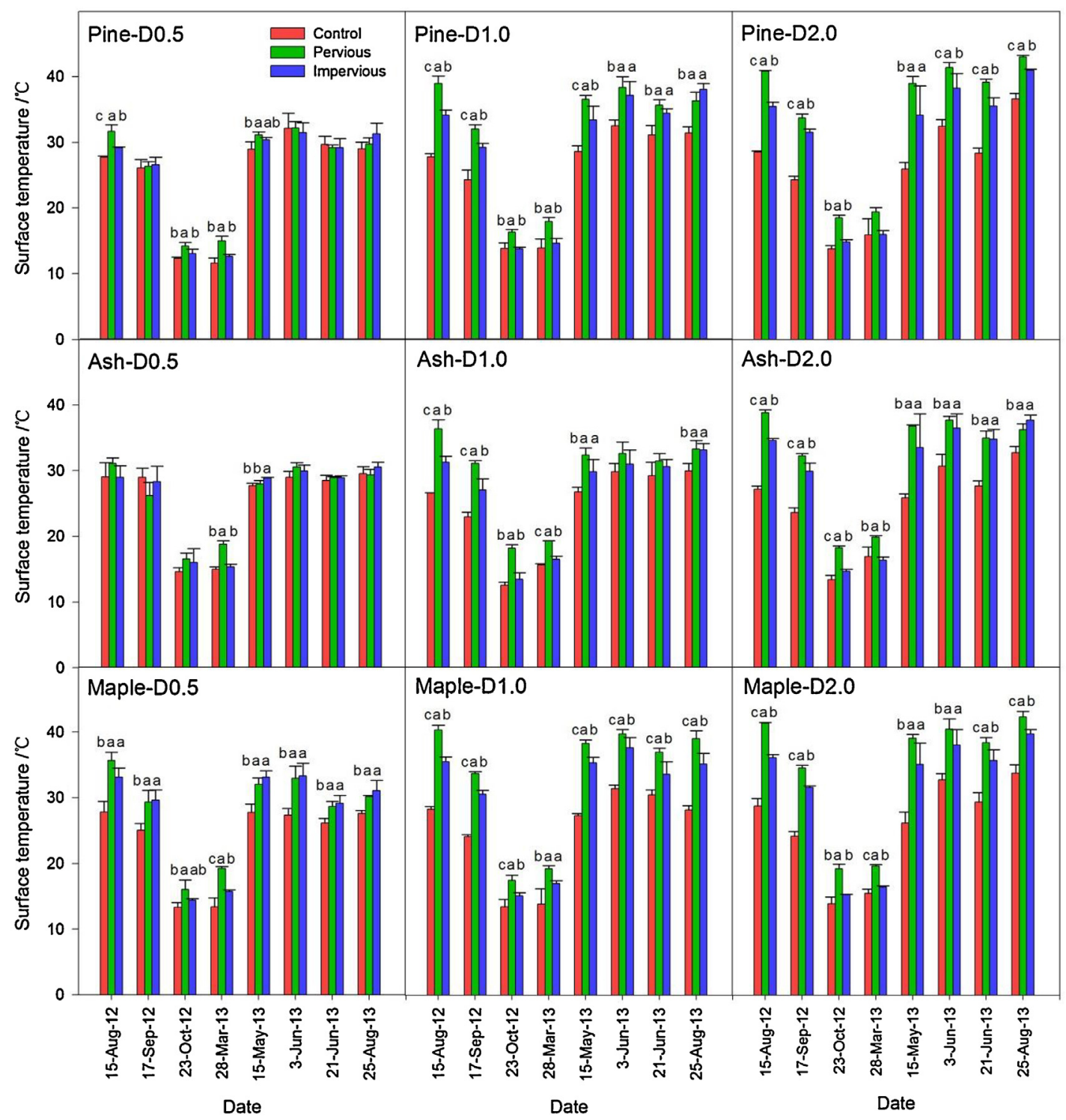

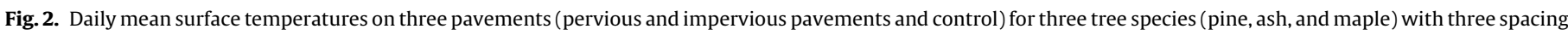

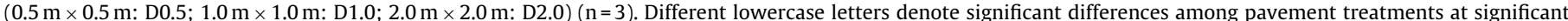
level of 0.05 .

rate and mean surface temperature $\left(R^{2}=0.49, P<0.001\right)$ and mean soil moisture $\left(R^{2}=0.25, P=0.010\right)$ (Fig. 5). Partial correlation analysis showed that the survival rate of maple was negatively related to surface temperature significantly under the variable of soil moisture controlled $(P<0.01)$ (Table. 4$)$. No significant relationships were found between survival rate and mean surface temperature and soil moisture for pine and ash.

\subsection{The relationship between tree growth and surface temperature and soil moisture}

There were significantly negative linear relationships between tree height and mean surface temperature and mean soil moisture for pine $\left(R^{2}=0.58, P<0.001 ; R^{2}=0.67, P<0.001\right.$, respectively) and maple $\left(R^{2}=0.93, P<0.001 ; R^{2}=0.28, P=0.005\right.$, respectively), and insignificantly linear relationships between tree height and mean surface temperature and soil moisture for ash $\left(R^{2}=0.0016\right.$, $P>0.05 ; R^{2}=0.14, P>0.05$, respectively) (Fig. 6). Partial correlation analysis showed that tree height of maple was negatively related to surface temperature significantly under the variable of soil mois- ture controlled $(P<0.001)$ and tree height of pine was negatively related to soil moisture significantly under the variable of surface temperature controlled $(P<0.05)$ (Table. 4$)$.

There were significantly negative linear relationships between tree basal diameter and mean surface temperature for maple $\left(R^{2}=0.49, P<0.001\right)$, and there were significantly positive linear relationship for ash $\left(R^{2}=0.23, P<0.05\right)$ (Fig. 7). Partial correlation analysis showed that tree basal diameter of maple was negatively related to surface temperature significantly under the variable of soil moisture controlled $(P<0.001)$ and tree basal diameter of ash was positively related to soil moisture significantly under the variable of surface temperature controlled $(P<0.01)$ (Table. 4$)$.

\section{Discussion}

\subsection{The impacts of pavements}

\subsubsection{Surface temperature}

Our results showed that pavement type significantly increased surface temperature (Table 1 and Fig. 2), which is consistent 


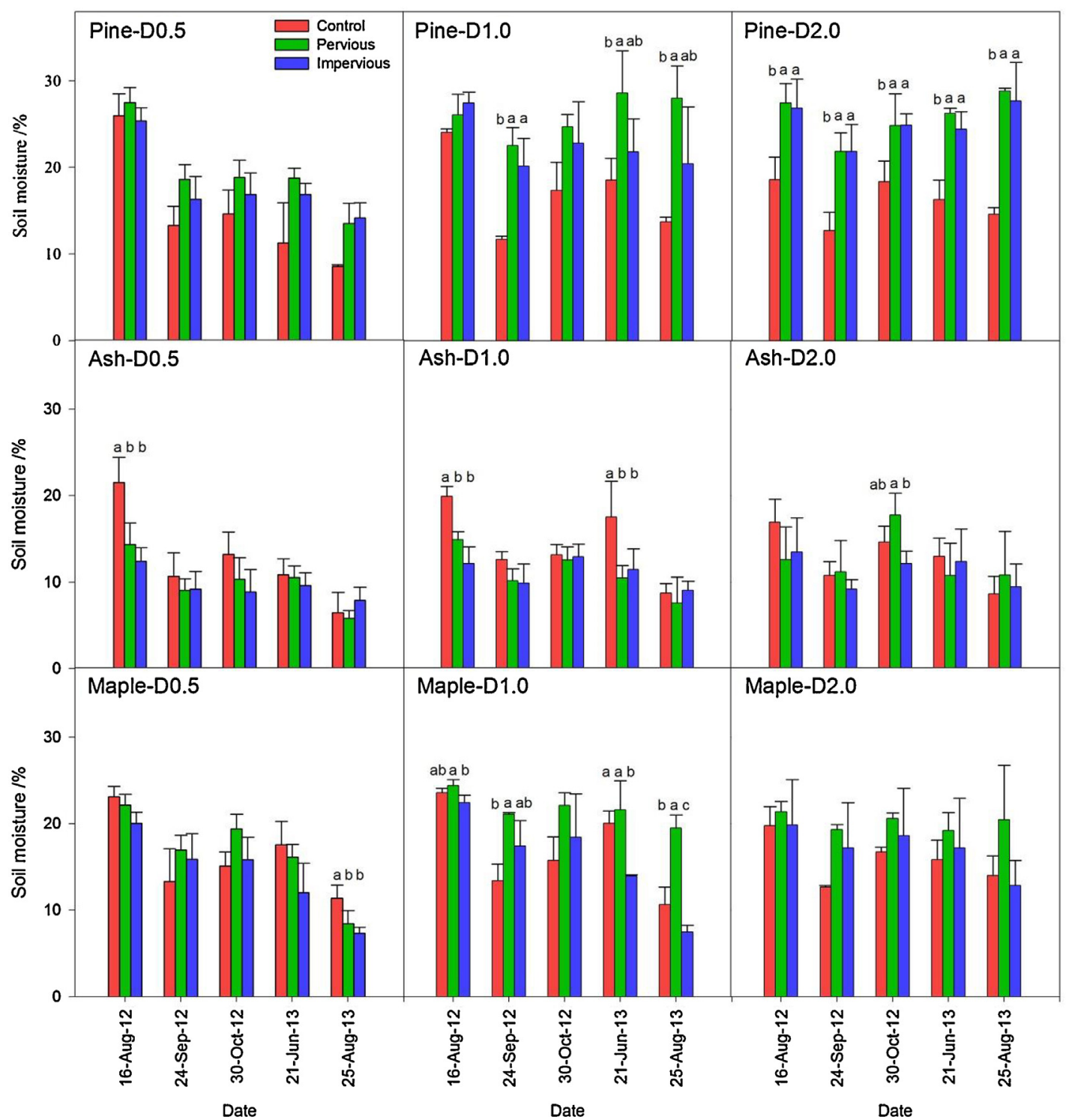

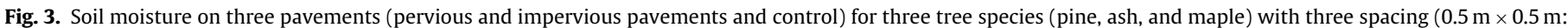
D0.5; $1.0 \mathrm{~m} \times 1.0 \mathrm{~m}$ : D1.0; $2.0 \mathrm{~m} \times 2.0 \mathrm{~m}$ : D2.0) $(\mathrm{n}=3)$. Different lowercase letters denote significant differences among pavement treatments at significant level of 0.05 .
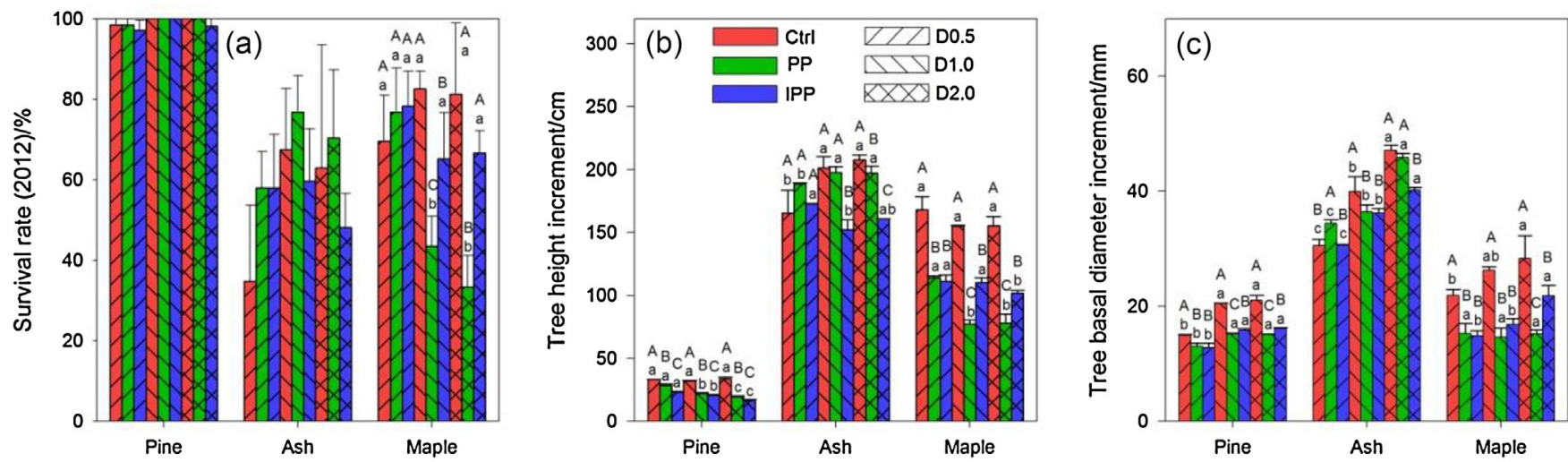

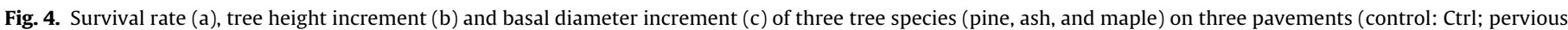

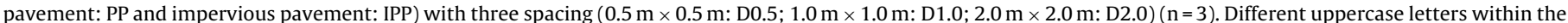

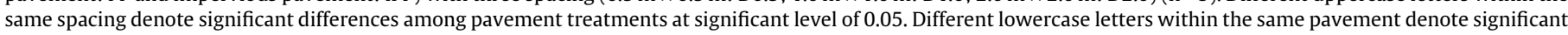
differences among spacing treatments at significant level of 0.05 . 
Table 3

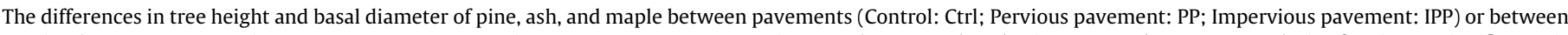

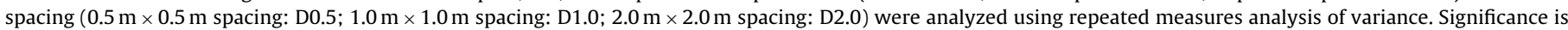
indicated by ${ }^{*} P<0.05$; ${ }^{* *} P<0.01$; ns: not significant.

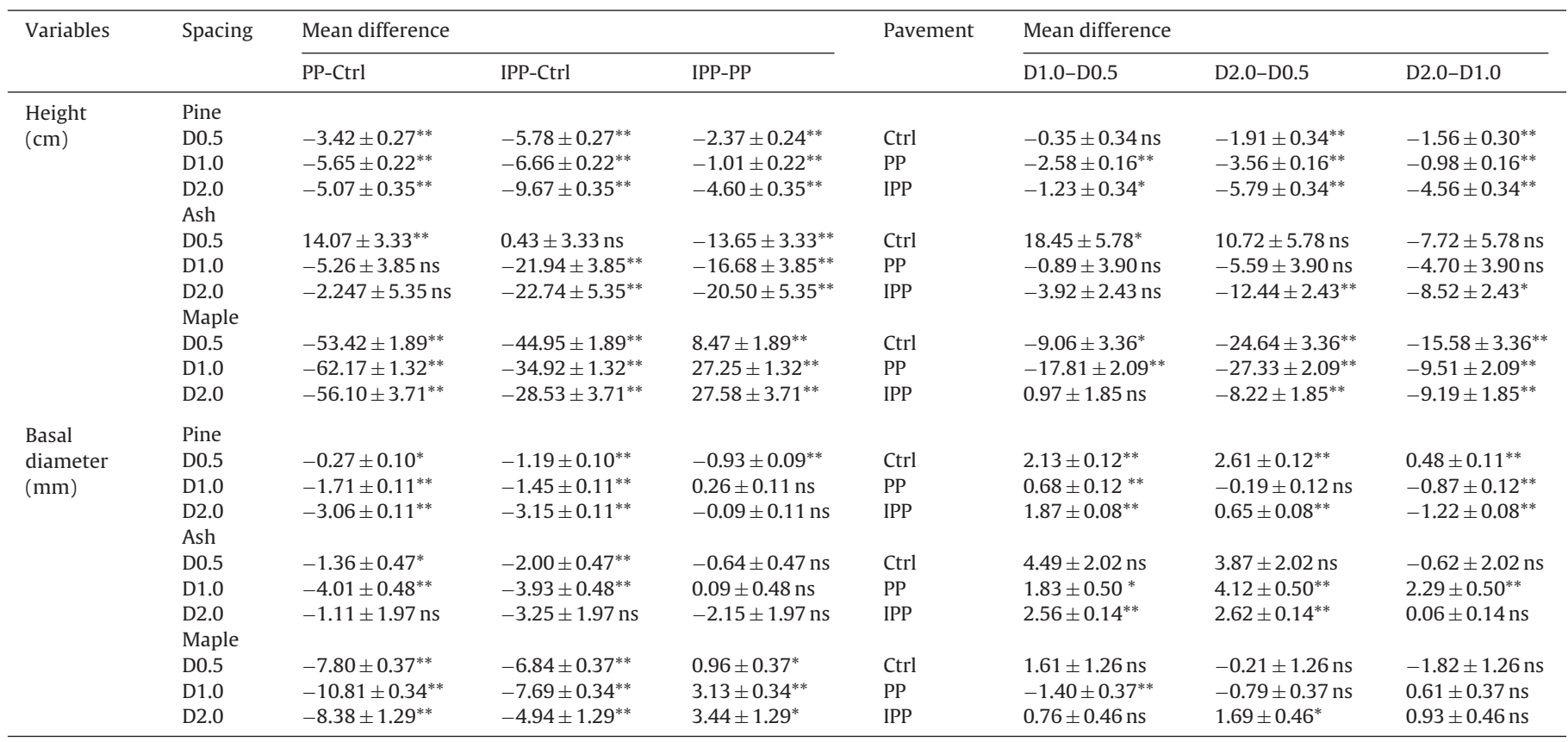

with previous reports that surface temperatures of pavements were higher than that of vegetated or mulch landscape surfaces (Celestian \& Martin, 2004; Kjelgren \& Montague, 1998; Montague \& Kjelgren, 2004). Kjelgren and Montague (1998) recorded that paved land surface temperatures were as much as $20^{\circ} \mathrm{C}$ to $25^{\circ} \mathrm{C}$ higher than surrounding surfaces landscaped with vegetation. In our study, the pervious and impervious material was grey brick, which has low thermal capacity, which likely explains the higher surface temperatures (Kjelgren \& Montague, 1998). Asaeda, Ca, and Wake (1996) reported that surface temperature increased under pavement because the relatively large heat storage capacity of pavements (e.g. asphalt) which allow it to absorb and store substantial amounts of heat. Surface temperature was higher on pervious pavement than impervious pavement, which is attributed to higher reflectivity of impervious pavement than pervious pavement.

\subsubsection{Soil moisture}

It was anticipated that soil moisture would be low because pavement can intercept rainwater before it enters the soil. However, low soil moisture was not always observed. Soil moisture under the control was higher than that under both impervious and pervious pavement for ash in most cases and that under impervious pavement for pine and maple in some cases (Fig. 3). In contrast, pavements increased soil moisture for pine and maple for most measurements (Fig. 3). This is because pavement in our experiment cannot prevent rainwater from penetrating into soil. The rainwater intercepted by pavement could flow into the pits in which trees were planted, and then penetrate into soil. Furthermore, pavement blocked upward evaporation of soil moisture. So, higher soil moisture could be observed under pavements in comparison to the control. The magnitude of biologically-mediated hydraulic redistribution of soil water by roots would also impact the differences (Yu et al., 2013). Wang, Han, Zhang, Dang, and Qu (2012) found higher soil moisture under pavement when trees were planted at high spacing. Viswanathan (2010) reported there were no effects of pavement on soil moisture. Thus, more experiments should be conducted to understand the response of soil moisture to pave- ment and its relations with external factors such as soil texture, pavement materials, soil temperature, rainfall, plant spacing, and seasons.

\subsubsection{Tree survival rate}

Previous studies have shown that tree survival is influenced by many factors, including species and spacing (He \& Duncan, 2000), ground cover (Gillespie, Miller, \& Johnson, 1995), soil compaction (Ampoorter, De Frenne, Hermy, \& Verheyen, 2011), temperature (Niu, Zhang, Liu, Guo, \& Zhang, 2012), and atmospheric carbon dioxide and nitrogen deposition (Sefcik, Zak, \& Ellsworth, 2007). Our study showed that the influences of pavement on tree survival rates were specific to tree species, and only maple's survival rate was significantly influenced by pavement. This may be because maple is intolerant to high temperature. Our results showed that survival rates significantly decreased with increased temperature. Kolb and Robberecht (1996) have reported that low seedling survival was related to high soil surface temperatures in many environments. Other factors might influence tree survival under pavement. For example, soil compaction significantly reduces tree survival on silty soils (Ampoorter et al., 2011), and $\mathrm{CO}_{2}$ concentrations, which were greatly enhanced under pavement, reduce root productivity, which could potentially decrease survival rates (Viswanathan et al., 2011).

\subsubsection{Tree growth}

Tree growth was significantly reduced by pavement for pine and maple at all spacing and for ash at $1.0 \mathrm{~m} \times 1.0 \mathrm{~m}$ and $2.0 \mathrm{~m} \times 2.0 \mathrm{~m}$ spacing (Fig. 4(b) and (c)). In this study, we measured two important factors: surface temperature and soil moisture. Pavement surfaces can increase soil temperatures above levels for optimal physiological functioning of trees (Celestian \& Martin, 2004). Tree height was significantly negatively related to mean surface temperature for pine and maple (Fig. 6), and tree basal diameter was significantly negatively related with mean surface temperature for maple (Fig. 7). It is commonly believed that pavements reduce soil moisture by precluding infiltration; however, other studies have indicated that trees may suffer from too much, rather than too little 

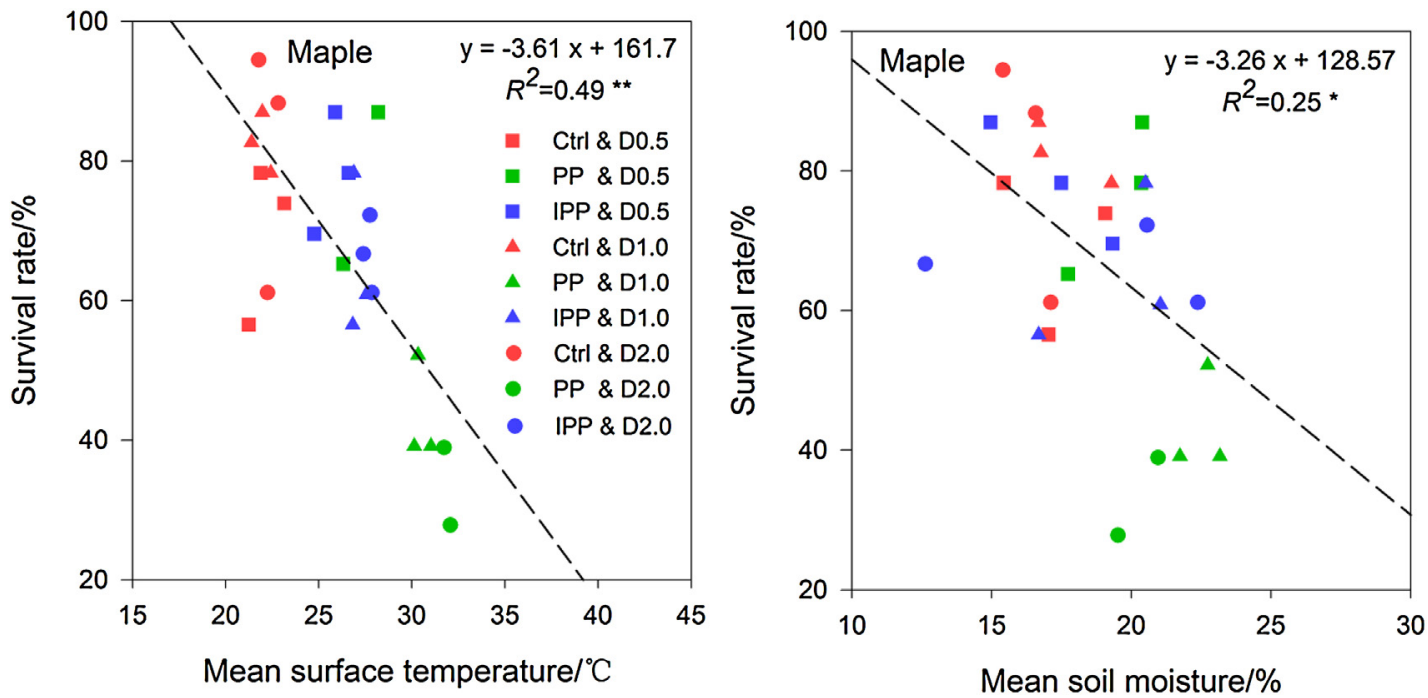

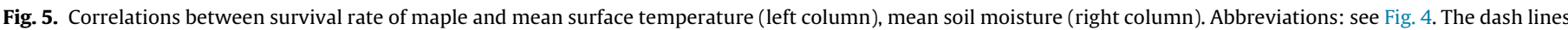
represent the best-fit linear regressions for treatments. Significance is indicated by $P<0.05$; ${ }^{* *} P<0.01$.

Table 4

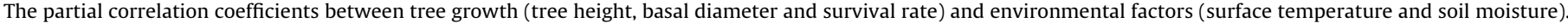
Significance is indicated by ${ }^{*} P<0.05 ;{ }^{* *} P<0.01$; ns: not significant.

\begin{tabular}{|c|c|c|c|}
\hline \multirow[t]{2}{*}{ Tree species } & \multirow[t]{2}{*}{ Tree growth variables } & \multicolumn{2}{|c|}{ Partial correlation coefficients } \\
\hline & & $\begin{array}{l}\text { Surface temperature } \\
\text { (Control variable: Soil } \\
\text { moisture) }\end{array}$ & $\begin{array}{l}\text { Soil moisture } \\
\text { (Control variable: Surface } \\
\text { temperature) }\end{array}$ \\
\hline \multirow[t]{2}{*}{ Pine } & Height & $-0.188 \mathrm{~ns}$ & $-0.490 *$ \\
\hline & Basal diameter & $0.116 \mathrm{~ns}$ & $-0.239 \mathrm{~ns}$ \\
\hline \multirow[t]{2}{*}{ Ash } & Height & $0.010 \mathrm{~ns}$ & $0.373 \mathrm{~ns}$ \\
\hline & Basal diameter & $0.340 \mathrm{~ns}$ & $0.531^{* *}$ \\
\hline \multirow[t]{3}{*}{ Maple } & Height & $-0.951^{* *}$ & $0.143 \mathrm{~ns}$ \\
\hline & Basal diameter & $-0.647^{* *}$ & $0.085 \mathrm{~ns}$ \\
\hline & Survival rate & $-0.574^{* *}$ & $-0.123 \mathrm{~ns}$ \\
\hline
\end{tabular}

water (Berrang et al., 1985), though it is unclear whether this is due to pavement. In our study, tree height were significantly negatively related to soil moisture for pine and maple (Fig. 6), while tree basal diameter was significantly positively related with soil moisture for ash (Fig. 7). So, the influence of pavement on tree growth might be species-specific. Excluding the relationship between surface temperature and soil moisture, pine height was significantly related with soil moisture but not surface temperature (Table 4). The reason might be that pine is a heliophilous and drought tolerance plant, the significant increase in soil moisture due to pavement could negatively influence pine growth. Perhaps this is also attributed to soil anaerobic condition induced by pavement that influences pine growth.

\subsection{Different impacts between pervious and impervious pavements}

Pervious pavement has a high infiltration rate of water through the surface into the subsoil (Bean et al., 2007; Dietz, 2007). In our study, soil moisture in pervious pavement was higher than in impervious pavement in most cases, especially for pine and maple trees. However, these differences were not significantly different in some cases. Some previous studies have confirmed that pervious pavement increases soil moisture compared to impervious pavement (Mullaney et al., 2015; Volder et al., 2009), while others have shown that pervious pavement does not effectively improve soil moisture compared to impervious pavement (Morgenroth \& Buchan, 2009; Volder et al., 2009). Another study showed that pervious pavement had greater soil moisture than impervious pavement for the plot closest to the stem, while no effects of pavement on soil moisture for the outer plot (Viswanathan, 2010). Volder et al. (2009) proposed that soil moisture in deeper soil layers below the pervious pavement were greater than that of impervious pavement in all seasons except in the summer. Mullaney et al. (2015) showed that the soil moisture under pervious pavement was higher compared to under impervious pavement in the sandy loam, but lower in the clay soil, and soil moisture under pervious pavement was related to the depth of the underlying base layer. This may be because soil moisture is vulnerable to many external factors such as soil texture, pavement materials, soil temperature, rainfall, plant spacing, and seasons. Thus more experiments should be conducted to assess the influence of pavement on the response of soil moisture.

Pervious pavement could provide the trees with an advantage compared to impervious pavement by potentially providing improved conditions for tree root growth and production (Morgenroth, Buchan, \& Scharenbroch, 2013), as well as increased tree stem height, diameter, and biomass (Morgenroth \& Visser, 2011). Our experiment confirmed that pine and ash trees (but not maple) surrounded by pervious pavements were taller and had greater basal diameter than trees surrounded by impervious pavement. It seems likely that differences in growth must be associated with the permeability of the pervious pavement, and thus, higher soil moisture for pine and ash trees. Although soil moisture for maple trees was higher in pervious pavement than in impervious pavement, the much higher surface temperatures in pervious pave- 


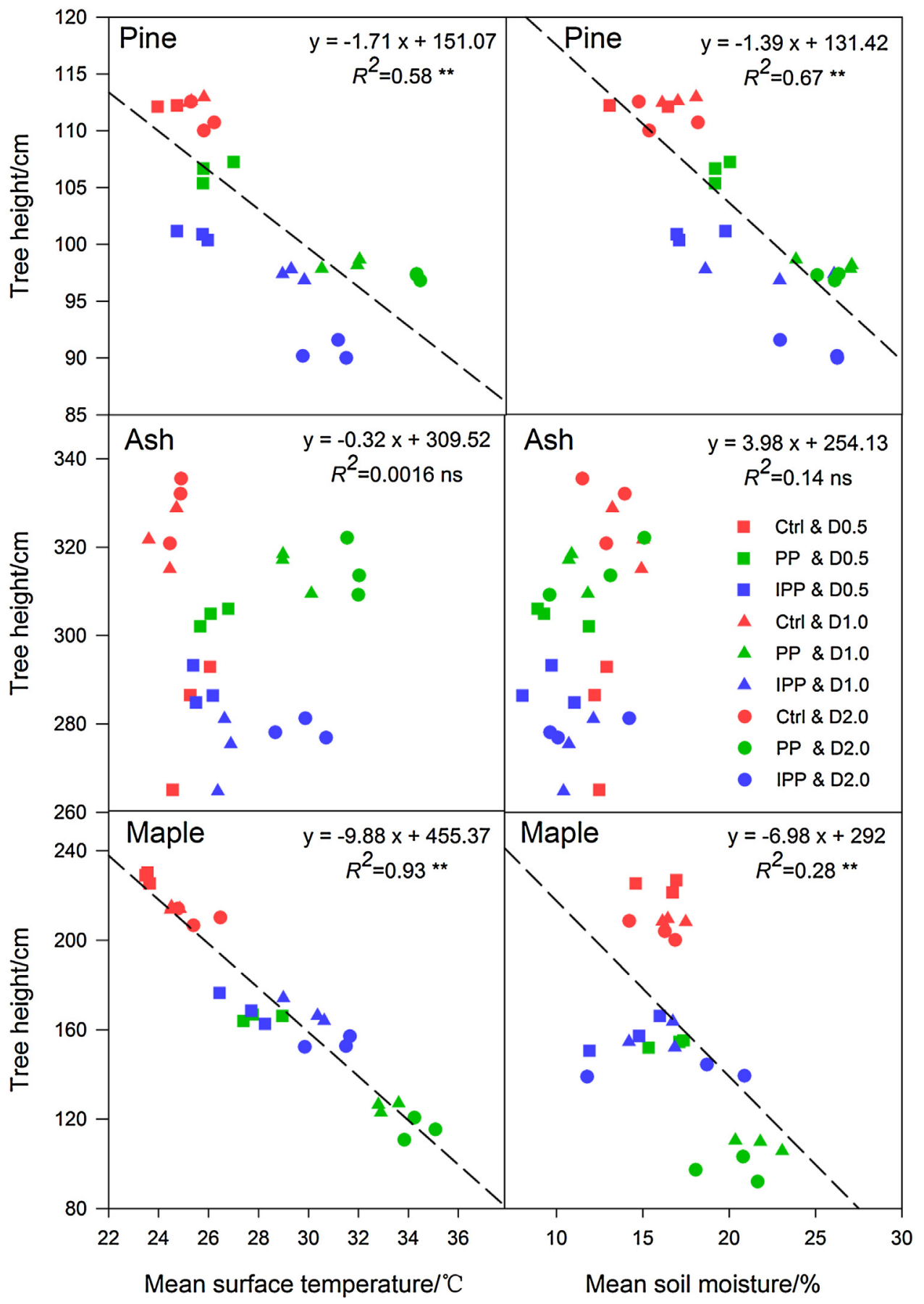

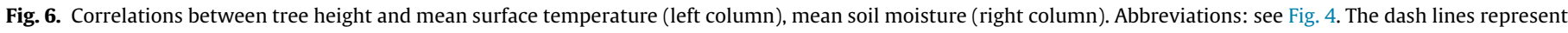
the best-fit linear regressions for treatments. Significance is indicated by ${ }^{*} P<0.05$; ${ }^{* *} P<0.01$; ns: not significant.

ment compared to impervious pavement outweighed the benefits of permeability. This led to lower growth for maple in the pervious pavement. Volder et al. (2009) found that the relative growth rates of tree trunk diameters were similar across three different pavement types (no pavement, pervious, and impervious pavements).

One of the interesting results from our study is that there was higher surface temperature on pervious pavement than on impervious pavement. This may be because pervious pavement has more pores filled with air, which prevents heat from transferring downward so that surface temperature rises quickly. The higher surface temperature on pervious pavement could increase heating stress to tree seedlings, and caused negative impact tree seedling sur- vival rate, height and basal diameter. Thus, we should select species tolerant to high temperature when planting in pervious pavement.

\subsection{Tree species influences}

In our study, the impacts of pavements on surface temperature, soil moisture, tree survival rate, and tree growth varied with tree species. The differences in size and growth rates of the three tree species resulted in changes in surface temperature due to different levels of shading and transpiration cooling, and in soil moisture by different degrees of water uptake. Although surface temperature was increased on pavements, the degree of increase varied with different tree species. The increase for maple was the highest, fol- 


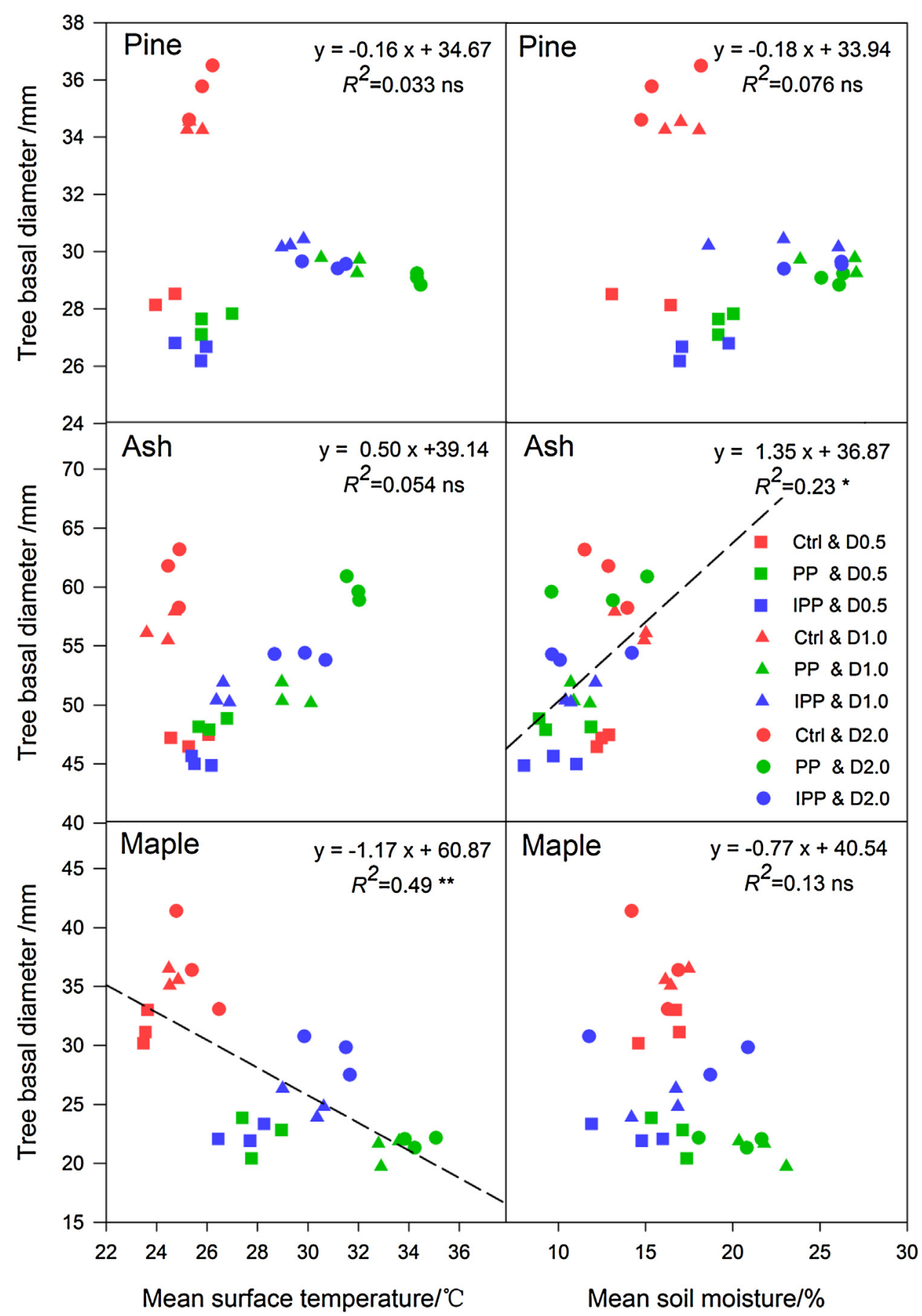

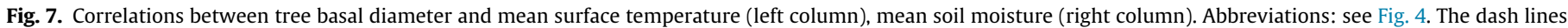
represent the best-fit linear regressions for treatments. Significance is indicated by ${ }^{*} P<0.05$; ${ }^{* *} P<0.01$; ns: not significant.

lowed by pine and ash. The differences of soil moisture between pavements and the control also varied with tree species. For pine, pavements increased soil moisture at the depth of $20 \mathrm{~cm}$, while for ash, pavements decreased soil moisture, as compared with control. For maple, soil moisture was highest in the pervious pavement, followed by the control and impervious pavement.

The level of pavement effects on seedling survival and growth depends on tree species (Gomez, Powers, Singer, \& Horwath, 2002; Heninger et al., 2002). Grabosky et al. (2001) surveyed three tree species (Tiliacordata Mill. 'Olympic'; Acer campestre L.; Malus sp. Mill. 'Adirondack'), and indicated that there was an increase in root length of Acer and Tilia in the experimental pavement profile versus the standard pavement profile and an increase in depth of the root zone for all species. Besides exposure to different surface temperature and soil moisture conditions, different tree species have different adaptability to the surrounding environment (Sefcik et al., 2007). In our study, the survival rate of pine was not significantly influenced by pavements because pines have high survival rate and more tolerant to increased surface temperature. Maple with low survival rates was significantly influenced by pavements.

\subsection{Tree spacing influences}

Surface temperature was decreased with decreasing tree spacing (Fig. 2), however, higher spacing of tree planting have been associated with increased soil moisture (Wang et al., 2012). 
Although there were no statistically significant differences in soil moisture between $1.0 \mathrm{~m} \times 1.0 \mathrm{~m}$ and $2.0 \mathrm{~m} \times 2.0 \mathrm{~m}$ spacing in our study, both were higher than soil moisture in treatments with $0.5 \mathrm{~m} \times 0.5 \mathrm{~m}$ spacing. More trees would uptake more water and reduce soil moisture. Because low tree spacing alleviates increased surface temperatures caused by pavement, trees with lower spacing will have higher survival rates. In our study, survival rates of maple were negatively related to surface temperature. Therefore, low-spacing plantings could alleviate the negative effects of pavements and increase maple survival. Tree height increased with decreasing spacing because trees themselves competed more strongly for light in low spacing situations.

This study improves understanding of how pervious and impervious pavements affected surface temperature and soil moisture, and subsequently tree survival and growth. However, there are lots of factors influencing the relationship between tree growth and land pavement. Morgenroth (2010) reported that pavement resulted in excessive surface temperature, extreme soil moisture, and root-limiting soil compaction, which induce in reduction of tree growth. Other soil factors (e.g., texture, nutrient, microbial community, oxygen and $\mathrm{CO}_{2}$ concentrations) also are changed by pavement, which would influence tree growth and necessitate more investigations.

This study shows that the surface temperature increased by pavement is the primary contributor to the reductions in tree survival and growth. However, there is a great uncertainty in the contribution of soil moisture changed by pavement to tree growth. In this study, soil moisture under impervious pavement is not always lower than the control as anticipated. The reason is that the pits layout on paved land for planning trees can flow rainwater into soil. In urban pavement setting, pits should be established when planting trees. So trees planted under pavement might be less stressed by preventing rainwater penetration. Therefore, alleviating the increased surface temperature induced by the pavement is important to guarantee tree survival and growth in urban tree planting and management.

In this study, we investigated how land pavement influences the growth of different urban trees at different spacing. This study provides supplementary information to the existing literature on the effects of various pavement types on the physiology of urban trees through successful determination of the impacts of pervious pavements on tree growth. However, the confounding effects of pavement type, tree species, and spacing on tree growth are very complex. It requires more measurements of the micro-environmental factors (e.g., soil nutrient, aeration, and water budget) as well as plant physiological and growth characteristics (e.g., photosynthesis, evapotranspiration, canopy shape and branch junction strength and diameter etc.) in order to more clearly explain the responses of plants to pavements. It is also important to monitoring more tree species in response to different characteristics of pavements (such as reflectivity, thermal capacity and infiltration rate) in long-term periods to better assess the effect of pavement on plant growth and health.

\section{Conclusions}

Planting trees on paved areas such as streets, squares, and parking lots has become more popular in urban environments as part of efforts to expand forest cover with limited available space. However, little is known about the impact of pavement on microenvironments, and the influence of pavement on tree growth. In this study, we used a factorial-design experiment involving three tree species commonly planted in North China cities with different pavement types and spacing. We assessed the modifications of pavements, tree species and spacing on surface temperature and soil moisture and their resulting impacts on tree growth. Most results could support the hypotheses that: (1) pavements increased surface temperature, (2) pervious pavement increased soil moisture compared to impervious pavement, (3) surface temperature and soil moisture both decreased with decreasing spacing, and (4) the presence of pavements reduced tree growth including height and basal diameter. This study also confirmed that tree growth was impacted by pavement-induced surface temperature because tree growth had a significantly negative relationship with mean surface temperature for pine and maple.

Interestingly, the effects of pavement on the microenvironment and tree growth varied with pavement type, tree species, and spacing. Surface temperature was higher on pervious pavement than on impervious pavement, and decreased with decreasing spacing. Soil moisture was not always higher in the control than in impervious pavement and higher in pervious pavement than impervious pavement. The pavement-induced reductions in tree growth were not always alleviated by pervious pavement because of the presence of strong heat stress. The confounding effects of pavement, tree species, and spacing require more measurements of the microenvironment as well as plant physiological and growth characteristics in order to more clearly explain the responses of plants to pavement. These findings also highlight the importance of monitoring the effect of pavements on several tree species for longer timeperiods to better assess the effect of pavement on plant growth, including the different effects of pervious and impervious pavement on plant growth.

\section{Acknowledgments}

This study has been supported by National Nature Science Foundation of China (41571053 and 71533005). We would also thank two anonymous referees for constructive review of this manuscript.

\section{References}

Ampoorter, E., De Frenne, P., Hermy, M., \& Verheyen, K. (2011). Effects of soil compaction on growth and survival of tree saplings: A meta-analysis. Basic and Applied Ecology, 12, 394-402.

Arnfield, A. J. (2003). Two decades of urban climate research: a review of turbulence, exchanges of energy and water, and the urban heat island. International Journal of Climatology, 23, 1-26.

Asaeda, T., Ca, V. T., \& Wake, A. (1996). Heat storage of pavement and its effect on the lower atmosphere. Atmospheric Environment, 30(3), 413-427.

Balakina, J. N., Makarova, O. V., Bondarenko, V. V., Koudstaal, L. J., Ros, E. J., Koolen, A. J., \& Loon, W. K. P. (2005). Simulation of oxygen regime of tree substrates. Urban Forestry \& Urban Greening, 4, 23-35.

Bean, E. Z., Hunt, W. F., \& Bidelspach, D. A. (2007). Field survey of permeable pavement surface infiltration rates. Journal of Irrigation and Drainage Engineering, 133, 249-255.

Beckett, K. P., Freer-Smith, P. H., \& Taylor, G. (1998). Urban woodlands: their role in reducing the effects of particulate pollution. Environmental Pollution, 99, 347-360.

Berrang, P., Karnosky, D. F., \& Stanton, B. J. (1985). Environmental factors affecting tree health in New York City. Journal of Arboriculture, 11(6), 185-189.

Bühler, O., Kristoffersen, P., \& Larsen, S. U. (2007). Growth of street trees in Copenhagen with emphasis on the effect of different establishment concepts. Arboriculture E Urban Forestry, 33, 330-337.

Celestian, S. B., \& Martin, C. A. (2004). Rhizosphere, surface, and air temperature patterns at parking lots in Phoenix, Arizona, U.S. Journal of Arboriculture, 30(4), 245-252.

D’Amato, N. E., Sydnor, T. D., Knee, M., Hunt, R., \& Bishop, B. (2002). Which comes first, the root or the crack? Journal of Arboriculture, 28(6), 277-282.

Dietz, M. E. (2007). Low impact development practices: a review of current research and recommendations for future directions. Water, Air, E Soil Pollution, 186, 351-363

Feng, G., Wu, L., \& Letey, J. (2002). Evaluating aeration criteria by simultaneous measurement of oxygen diffusion rate and soil-water regime. Soil Science, 167(8), 495-503.

Gillespie, A. R., Miller, B. K., \& Johnson, K. D. (1995). Effects of ground cover on tree survival and growth in filter strips of the Cornbelt Region of the midwestern US. Agriculture, Ecosystems E' Environment, 53, 263-270.

Gomez, A., Powers, R. F., Singer, M. J., \& Horwath, W. R. (2002). Soil compaction effects on growth of young ponderosa pine following litter removal in 
California's Sierra Nevada. Soil Science Society of America Journal, 66 1334-1343.

Grabosky, J., \& Gilman, E. (2004). Measurement and prediction of tree growth reduction from tree planting space design in established parking lots. Journal of Arboriculture, 30(3), 154-164

Grabosky, J., Bassuk, N., Irwin, L., \& Van Es, H. (2001). Shoot and root growth of three tree species in sidewalks. Journal of Environmental Horticulture, 19(4), 206-211

Graves, W. R. (1994). Urban soil temperatures and their potential impact on tree growth. Journal of Arboriculture, 20(1), 24-27.

He, F. L., \& Duncan, R. P. (2000). Density-dependent effects on tree survival in an old-growth Douglas fir forest. Journal of Ecology, 88, 676-688.

Heninger, R., Scott, W., Dobkowski, A., Miller, R., Anderson, H., \& Duke, S. (2002). Soil disturbance and 10-year growth response of coast Douglas-fir on nontilled and tilled skid trails in the Oregon Cascades. Canadian Journal of Forest Research, 32, 233-246.

Kjelgren, R., \& Montague, T. (1998). Urban tree transpiration over turf and asphalt surfaces. Atmospheric Environment, 32, 35-41.

Kolb, P. F., \& Robberecht, R. (1996). High temperature and drought stress effects on survival of Pinus ponderosa seedlings. Tree Physiology, 16, 665-672.

Kozlowski, T. T. (1999). Soil compaction and growth of woody plants. Scandinavian Journal of Forest Research, 14, 596-619.

Lakovoglou, V., Thompson, J., Burras, L., \& Kipper, R. (2001). Factors related to tree growth across urban-rural gradients in the Midwest. USA.Urban Ecosystems, 5(1), 71-85.

Lawrence, A. B., Escobedo, F. J., Staudhammer, C. L., \& Zipperer, W. (2012). Analyzing growth and mortality in a subtropical urban forest ecosystem. Landscape and Urban Planning, 104, 85-94.

Lee, J. G., \& Heaney, J. P. (2003). Estimation of urban imperviousness and its impacts on storm water systems. Journal of Water Resources Planning and Management, 129, 419-426.

Local Chronicles Office of Changping District of Beijing. (2012). Beijing Changping Yearbook, 2012. Beijing: The History of the Communist Party of China Publishing House [in Chinese].

Lohr, V. L., Pearson-Mims, C. H., Tarnai, J., \& Dillman, A. (2004). How urban residents rate and rank the benefits and problems associated with trees in cities. Journal of Arboriculture, 30, 28-35.

Lu, J. W. T., Svendsen, E. S., Campbell, L. K., Greenfeld, J., Braden, J., King, K. L., et al. (2010). Biological, social, and urban design factors affecting young street tree mortality in New York City. Cities and the Environment, 3(1), 1-15.

Marosz, A., \& Nowak, J. S. (2008). Effect of salinity stress on growth and macroelements uptake of four tree species. Dendrobiology, 59, 23-29.

Martin, C. A., \& Ingram, D. L. (1991). Root growth of southern magnolia following exposure to high root-zone temperatures. HortScience, 26(4), 370-371.

Montague, T., \& Kjelgren, R. K. (2004). Energy balance of six common landscape surfaces and the influence of surface properties on gas exchange of four containerized tree species. Scientia Horticulturae, 100, 229-249.

Morgenroth, J., \& Buchan, G. (2009). Soil moisture and aeration beneath pervious and impervious pavements. Arboriculture E Urban Forestry, 35(3), 135-141.

Morgenroth, J., \& Visser, R. (2011). Above-ground growth response of Platanus orientalis to porous pavements. Arboriculture E' Urban Forestry, 37, 1-5.

Morgenroth, J., Buchan, G., \& Scharenbroch, B. C. (2013). Belowground effects of porous pavements-soil moisture and chemical properties. Ecological Engineering, 51, 221-228.

Morgenroth, J. (2010). The effect of porous concrete paving on underlying soil conditions and growth of Platanus orientalis. A thesis for Degree of Doctor of Philosophy in Forestry. Canterbury: School of Forestry University of Canterbury.

Morgenroth, J. (2011). Root growth response of Platanus orientalis to porous pavements. Arboriculture E Urban Forestry, 37(2), 45-50.

Mueller, E. C., \& Day, T. A. (2005). The effect of urban ground cover on microclimate, growth and leaf gas exchange of oleander in Phoenix, Arizona. International Journal of Biometeorology, 49, 244-255.

Mullaney, J., \& Lucke, T. (2014). Practical review of pervious pavement designs. Clean-Soil, Air, Water, 42, 111-124.
Mullaney, J., Lucke, T., \& Trueman, S. J. (2015). The effect of permeable pavements with an underlying base layer on the growth and nutrient status of urban trees. Urban Forestry E Urban Greening, 14, 19-29.

Niu, S. N., Zhang, P. D., Liu, J., Guo, D., \& Zhang, X. M. (2012). The effect of temperature on the survival growth, photosynthesis, and respiration of young seedlings of eelgrass Zostera marina L. Aquaculture, 350-353, 98-108.

Philip, E., \& Azlin, Y. N. (2005). Measurement of soil compaction tolerance of Lagestromia speciosa (L.) Pers. using chlorophyll fluorescence. Urban Forestry \& Urban Greening, 3(3-4), 203-208.

Rahman, M. A., Stringer, P., \& Ennos, A. R. (2013). Effect of pit design and soil compaction on performance of Pyrus calleryana street trees in the establishment period. Arboriculture EUUrban Forestry, 39, 256-266.

Ridder, K. D., Adamec, V., Bañuelos, A., Bruse, M., Bürger, M., Damsgaard, O., et al. (2004). An integrated methodology to assess the benefits of urban green space. Science of the Total Environment, 334(-335), 489-497.

Sefcik, L. T., Zak, D. R., \& Ellsworth, D. S. (2007). Seedling survival in a northern temperate forest understory is increased by elevated atmospheric carbon dioxide and atmospheric nitrogen deposition. Global Change Biology, 13, 132-146.

Shashua-Bar, L., Potchter, O., Bitan, A., Boltansky, D., \& Yaakov, Y. (2010). Microclimate modelling of street tree species effects within the varied urban morphology in the Mediterranean city of Tel Aviv, Israel. International Journal of Climatology, 30, 44-57.

Su, Y. W., \& Sun, M. J. (2006). Photosynthetic rates and antioxidant enzyme activity of Platanus occidentalis growing under two levels of air pollution along the streets of Seoul. Journal of Plant Biology, 49(4), 315-319.

Tang, C. S., Shi, B., Gao, L., Daniels, J. L., Jiang, H. T., \& Liu, C. (2011). Urbanization effect on soil temperature in Nanjing, China. Energy and Buildings, 43(11), 3090-3098.

Tong, L., Wang, X. K., Zheng, F. X., Geng, C. M., Wang, W., Yin, B. H., et al. (2011). Effect of Ethylenediurea (EDU) on growth of ozone-stressed rice (Oryza sativa L.) and wheat (Triticum aestivum L.). Asian Journal of Ecotoxicology, 3, 272-280 [in Chinese].

Viswanathan, B., Volder, A., Watson, W. T., \& Aitkenhead-Peterson, J. A. (2011). Impervious and pervious pavements increase soil $\mathrm{CO}_{2}$ concentrations and reduce root production of American sweetgum (Liquidambar styraciflua). Urban Forestry \& Urban Greenning, 10, 133-139.

Viswanathan, B. (2010). Effect of pervious and impervious pavement on the rhizospher of American Sweetgum (Liquidambar styraciflua). Master of Science Thesis. Texas: Texas A\&M University

Volder, A., Watson, T., \& Viswanathan, B. (2009). Potential use of pervious concrete for maintaining existing mature trees during and after urban development. Urban Forestry \& Urban Greening, 8, 249-256.

Volder, A., Viswanathan, B., \& Watson, W. T. (2014). Pervious and impervious pavement reduce production and decrease lifespan of fine roots of mature Sweetgum trees. Urban Ecosystem, 17, 445-453.

Wang, Y. P., Han, M. Y., Zhang, L. S., Dang, Y. J., \& Qu, J. T. (2012). Variation characteristics of soil moisture in apple orchards of Luochuan County, Shaanxi Province of Northwest China. Chinese Journal of Applied Ecology, 23(3), 731-738 [in Chinese].

Xiao, Q., \& McPherson, E. G. (2002). Rainfall interception by Santa Monica's municipal urban forest. Urban Ecosystems, 6, 291-302.

Yu, T. F., Feng, Q., Si, J. H., Xi, H. Y., Li, Z. X., \& Chen, A. F. (2013). Hydraulic redistribution of soil water by roots of two desert riparian phreatophytes in northwest China's extremely arid region. Plant and Soil, 372, 297-308.

Zhao, D., Li, F., Wang, R. S., Yang, Q. R., \& Ni, H. S. (2012). Effect of soil sealing on the microbial biomass, $\mathrm{N}$ transformation and related enzyme activities at various depths of soils in urban area of Beijing. China. Journal of Soils and Sediments, 12, 519-530.

Zhao, J. J., 2010. Species composition and spatial distribution of urban plants within the built-up areas of Beijing, China. A thesis for Degree of Doctor of Natural Science, p47, Research Center for Eco-Environmental Sciences, Chinese Academy of Sciences; Beijing, [in Chinese]. 